A147-05-03-TD Cahyono

\title{
Keandalan Bangunan Rumah Contoh Tahan Gempa Pre-Pabrikasi
}

\author{
Tekat Dwi Cahyono ${ }^{1}$, Dodi Nandika ${ }^{2}$ \\ ${ }^{1)}$ Fakultas Pertanian Universitas Darussalam Ambon. Email: tekatdwicahyono@gmail.com \\ ${ }^{2)}$ Departeman Hasil Hutan IPB. Jl. Raya Dramaga Bogor 16680.
}

\begin{abstract}
Abstrak
Kerusakan bangunan selama penggunaan (service live) adalah hal yang tidak bisa dihindari. Namun dengan pemeliharan yang tepat, maka bangunan akan lebih awet dan mampu memaksimalkan fungsinya dengan baik. Oleh karena itu setiap bangunan setelah digunakan beberapa tahun harus di analisis, apakah masih layak atau beberapa bagiannya sudah mengalami kerusakan dan perlu pemeliharaan. Penelitian ini bertujuan untuk melakukan inspeksi terhadap keandalan bangunan rumah contoh tahan gempa prefabrikasi yang telah dibangun 10 tahun yang lalu. Metode yang digunakan adalah identifikasi terhadap bagian bagian bangunan, selanjutnya disesuaikan dengan indeks keandalan bangunan. Selain itu juga dilakukan diskripsi terhadap kerusakan dan rekomendasi penting terhadap kelanjutan fungsi bangunan. Hasil penelitian menunjukkan bahwa Bangunan tersebut masuk dalam kategori baik dengan nilai indeksnya adalah 80.3. Secara keseluruhan bangunan masih layak digunakan namun perlu dilakukan sedikit rekayasa dan perbaikan. Bangunan terlihat kurang bersih saat di survey karena tidak lagi digunakan untuk aktifitas harian. Rekomendasi penting adalah perbaikan drainase air, khususnya yang berhubungan dengan bangunan di sebelahnya sehingga kerusakan karena kelembaban bisa diminimalisir.
\end{abstract}

Kata kunci: Kerusakan Bangunan, pemeliharaan, service live.

\section{Pendahuluan}

Bangunan dibuat manusia dengan tiga aspek utama, yaitu keandalan, kenyamanan dan estetika. Keandalan merupakan kelayakan konstruksi, kekokohan, keawetan dan keandalannya terhadap faktor perusak, baik biologi, fisis maupun mekanis. Kenyamanan adalah cita rasa pemilik, pengguna atau yang sekedar menikmati bangunan itu merasa nyaman saat berada didalamnya. Sedangkan estetika lebih kepada seni untuk memperindah bangunan baik sebagian atau keseluruhannya.

Dalam masa pelayanannya bangunan akan mengalami penurunan keandalan, baik kekuatan maupun nilai estetik. Penurunan ini disebabkan karena proses mekanis, fisis, kimiawi, biotis, maupun aktivitas manusia (Watt 2009). Kerusakan mekanis adalah kerusakan yang disebabkan oleh gaya, baik gaya statis maupun gaya dinamis. Bentuk kerusakan ini misalnya berupa retakan, patahan, atau pecahan. Kerusakan fisis merupakan pelapukan yang disebabkan oleh faktor iklim (suhu dan kelembaban). Perubahan suhu dan kelembaban tersebut kadang-kadang terjadi secara mendadak. Gejala pelapukan yang terjadi misalnya berupa retakan-retakan mikro, keausan, pengelupasan lapisan cat, perubahan warna asli kayu, pemudaran cat dan sebagainya. Kerusakan kimia terutama disebabkan oleh air, baik berupa air kapiler maupun air hujan. Disamping itu udara yang terpolusi dan unsur-unsur lemak juga merupakan faktor pemacu yang tidak bisa diabaikan. Gejala pelapukan yang secara makroskopis teramati misalnya berupa pembusukan. Selanjutnya, pelapukan secara biotis yang disebabkan oleh pertumbuhan jasad renik. Pertumbuhan jasad renik tersebut tidak hanya mengganggu secara estetis saja tetapi juga mampu menimbulkan proses pembusukan ataupun noda dari hasil sekresi zat-zat organik yang dihasilkannya. Beberapa jenis jasad renik yang umumnya berperan adalah jamur, bakteri, dan lumut kerak. Di samping itu, serangan serangga terutama rayap, merupakan salah satu faktor perusak yang sangat membahayakan bahan bangunan dari kayu (Cahyono 2001, Lestari 2013, Cahyono 2016). Yang terakhir, kerusakan karena faktor manusia yang bisa berupa kesalahan rancang bangun, goresan 
benda tajam, corat-coret cat (vandalisme), kurangnya perawatan, dan lain-lain.

Kemunduran kualitas (deteriorasi) bangunan merupakan sesuatu yang tidak bisa dihindari, namun lajunya bisa ditekan dengan tindakan pemeliharaan dan perawatan, yang berarti juga menekan pembiayaan yang lebih besar untuk perbaikan atau pemugaran. Pemeliharaan dan perawatan yang baik akan memberikan efek penghematan biaya dan waktu, memberikan manfaat lebih lama, serta mendukung kinerja bangunan yang lebih baik. Bangunan yang dipelihara dan dirawat akan mencapai service life time sesuai yang direncanakan bahkan dapat melebihinya. Bangunan yang tidak dipelihara/dirawat akan lebih cepat mengalami deteriorasi.

Sebuah analisis kerusakan bangunan dilakukan terhadap rumah contoh tahan gempa pre-pabrikasi yang dibangun sejak tahun 2006 diantara bangunan-bangunan utama ruang kuliah dan laboratorium Departemen Hasil Hutan IPB. Faktor usia, desain dan kurangnya "kepedulian" terhadap bangunan ini mengakibatkan timbulnya beberapa kerusakan. Diawali dengan penjelasan desain dari bangunan tersebut, kegiatan ini akan dilanjutkan dengan diskripsi beberapa kerusakan yang terjadi dan kemungkinan rekomendasi yang bisa dilakukan untuk memperbaiki kerusakan tersebut.

\section{Sejarah dan Desain Rumah Tahan Gempa Pre-Pabrikasi}

Rumah prefabrikasi (disingkat prefab)
adalah pembangunannya cepat karena menggunakan modul hasil fabrikasi industri (pabrik). Komponen-komponennya dibuat dan sebagian dipasang oleh pabrik (off site). Setelah semuanya siap, kemudian diangkut ke lokasi, disusun kembali dengan cepat, sehingga tinggal melengkapi utilitas (utility) serta pengerjaan akhir (finishing). Beberapa manfaat lain adalah waktu konstruksi yang cepat, lingkungan pembangunan yang bersih dan biaya yang lebih terjangkau. Rumah prefab dirancang berdasar atas modul, maka keleluasaan pemilihan desain menjadi terbatas pada apa yang telah tersedia, namun ini tidak mengurangi minat masyarakat untuk menggunakannya (Roychansyah 2006, Surjokusumo et al. 2011, 小松幸平 2012).
Rumah tahan gempa Pre-Fabrikasi yang dilihat keandalannya dibangun pada tahun 2006, tepatnya mulai dibangun pada Bulan Juli hingga September 2006. Lokasi utama tapak pada saat awal dibangun berada dibelakang sudut Gedung Utama Fakultas Kehutanan Kampus Darmaga IPB. Kemudian dipindahkan di dekat Laboratorium Keteknikan Kayu, Bagian Rekayasa dan Desain Bangunan Kayu, Departemen Hasil Hutan IPB.

Bangunan Rumah dibuat dari Kayu Mangium (Acacia mangium) yang diperoleh dari hutan tanaman industri PT Inhutani II di Pulau Laut, Kalimantan Selatan. Kayu gergajian yang dipakai sudah dikeringkan hingga kadar air 14-16\%. Bangunan rumah contoh ini dapat diproduksi tiap-tiap komponen, yang kemudian dirangkai di lapangan. Komponen yang dibuat antara lain adalah pondasi, laintai, komponen lantai, komponen dinding, komponen langit-langit, komponen kuda-kuda dan komponen atap (Karlinasari et al. 2006).

Pondasi dirancang dibangun dengan ketinggian $50 \mathrm{~cm}$ diatas tanah untuk menghindari kelembaban akibat kontak langsung dengan tanah. Selain itu juga menghindarkan bangunan dari genangan dan mempermudah pengendalian rayap (Gambar 1). Desain dinding dibuat dengan model stress skin komponen memanfaatkan papan yang ditata sedemikain rupa membentuk sudut $45^{\circ}$ dari vertikal, dan saling tegak lurus antara komponen. Untuk menghindari timbulnya celah akibat penyusutan, maka ditambahkan bingkai antar pelat. Ada dua alternatif desain pada komponen dinding ini yaitu pada tiap panel dinding, papan-papan ditata sejajar seluruhnya dengan sudut $45^{\circ}$ terhadap vertikal, atau dapat pula papan-papan tiap panel dinding ditata saling tegak lurus antara pelat bawah dan pelat atas. Papan miring ini selain berfungsi estetis juga berfungsi pula sebagai komponen struktural (Gambar 2).

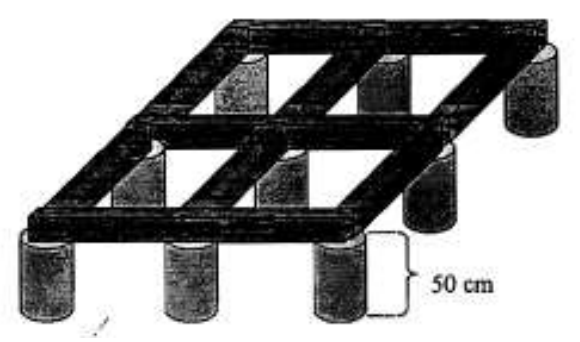

Gambar 1. Struktur pondasi tahan gempa 


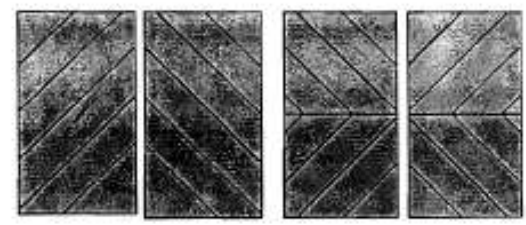

Gambar 2. Desain dinding model stress skin panel component

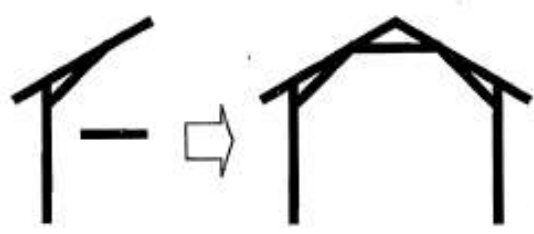

Gambar 3. Model Komponen atap rumah tahan gempa

Komponen atap terdiri dari komponen kuda-kuda, langit-langit dan atap (Gambar 3). Komponen kuda-kuda didesain menggunakan papan kayu yang dapat dibongkar dan dipasang dengan cepat. Kuda-kuda terbagi menjadi dua komponen yang dapat disatukan pada saat instalasi sehingga memudahkan pengiriman. Langit-langit dibuat dengan mempersiapkan komponen-komponen yang dapat disambung dengan mudah, sedangkan atap dapat menggunakan seng atau asbes. Tampak dengan dan pintu rumah pre-pabrikasi disajikan pada Gambar 4 dan 5.

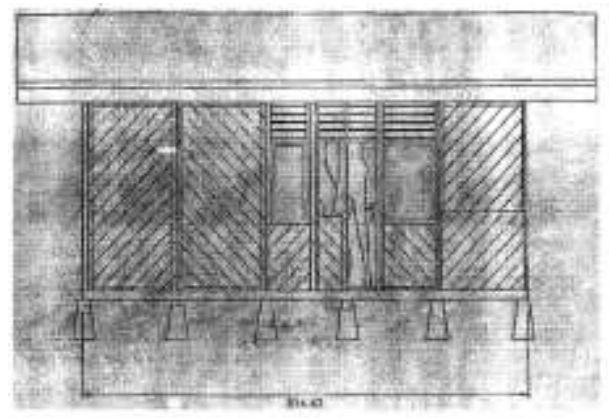

Gambar 4. Tampak Depan Gambar Rumah Tahan Gempa Pre-Pabrikasi

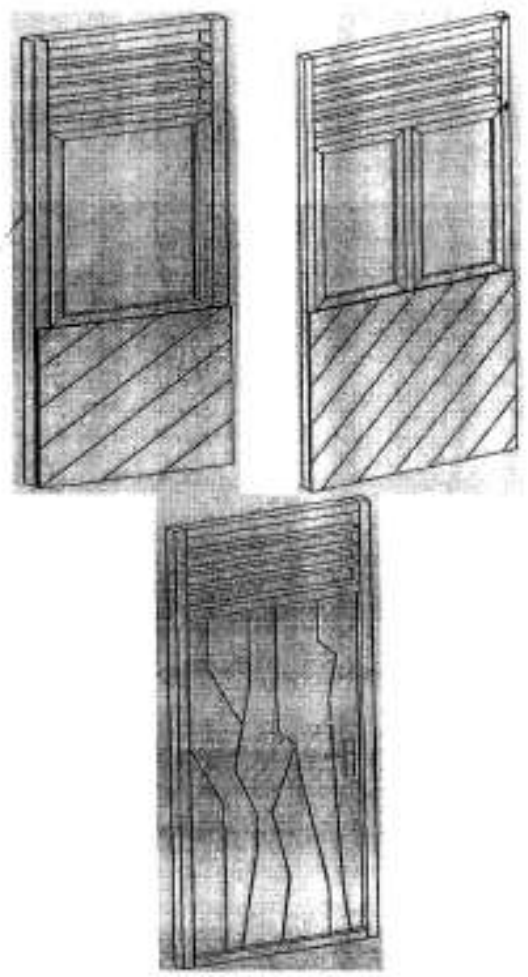

Gambar 5. Desain Pintu dan Jendela Rumah Tahan Gempa Pre-Pabrikasi

Ukuran keseluruhan rumah contoh ini adalah seluas $21 \mathrm{~m}^{2}$, atau setara dengan rumah sederhana tipe 21 . Rumah contoh ini terdiri dari satu ruangan utama yang dapat digunakan sebagai ruang tamu dan keluarga, satu kamar tidur dan terdapat sedikit lorong yang bisa digunakan sebagai dapur (Gambar 6). Bangunan ini menurut Karlinasari et al. (2006) membutuhkan kurang lebih $5 \mathrm{~m}^{3}$ kayu Akasia mangium. Alasan penggunaan jenis ini adalah hasil pengujian MOE dan MOR yang dilakukan oleh Surjokusumo et al. (2011) menunjukkan bahwa kayu mangium layak digunakan untuk struktural. 


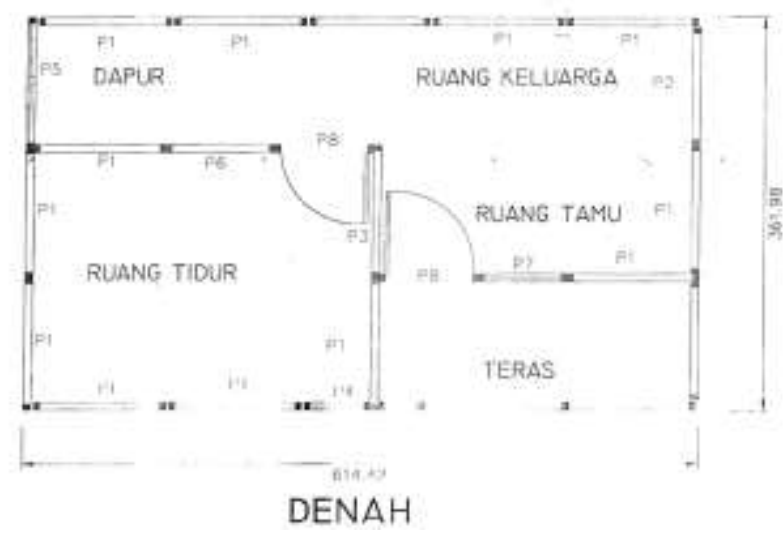

Gambar 6. Denah Rumah Contoh Tahan Gempa Pre-Pabrikasi

\section{Metodologi}

Tinjauan kerusakan bangunan
dilakukan secara langsung melalui pengamatan visual, kondisi bangunan kemudian dicatat dalam form isian audit serta didokumentasikan dengan kamera. Teknik pembobotan dilakukan terhadap kondisi bangunan yang diamati untuk selanjutnya dinilai kondisi bangunan untuk mengetahui keterandalan bangunan. Pengamatan dilakukan terhadap kuda-kuda, pondasi, dinding, langit-langit, kusen dan daun jendela, lantai, drainase dan utilitas.

Hasil pengamatan ditabulasi sesuai dengan bagian bangunan. Kriteria keterandalan bangunan dilakukan menurut kriteria yang ditetapkan oleh Departemen Permukiman dan Prasarana Wilayah (2002). Kriteria ini disusun menurut urutan komponen utama yang berpengaruh terhadap sebuah bangunan dan sudah diberikan skor untuk masing-masing bagian. Urutan pekerjaan secara singkat ditampilkan pada Gambar 7 berikut ini :

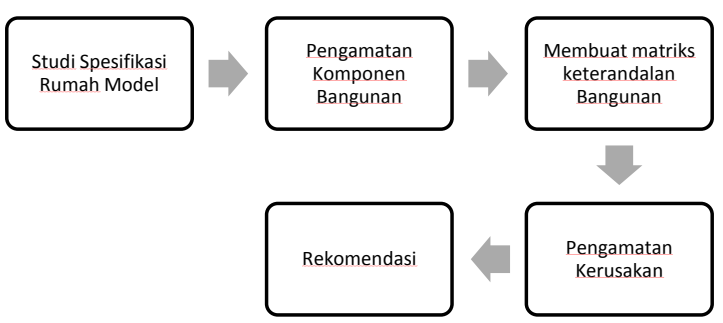

Gambar 7. Urutan pekerjaan analisis bangunan rumah tahan gempa pre-pabrikasi.

\section{Hasil dan Pembahasan Pengujian Keterandalan Bangunan}

Hasil pengamatan terhadap kondisi bangunan rumah contoh tahan gempa prepabrikasi disajikan pada Tabel 1. Tabel ini menunjukkan 9 objek pengamatan, disusun dari objek yang paling vital sampai yang hanya berfungsi sebagai estetika dan kenyamanan. Sebagian objek pengamatan pada Tabel 1, misalnya plafon dan drinase diberikan nilai 0 , karena pada bangunan contoh tahan gempa pre-pabrikasi tidak ditemukan plafon. Utilitas telekomunikasi diberikan nilai 4 , karena disediakan kabel akses internet di ruang kamar utama. Kriteria untuk dinding utama disesuaikan dengan bangunan kayu, misalnya slof, kolom dan kolom praktis semuanya terbuat dari kayu, sehingga kriterianya juga dimodifikasi untuk kayu. Secara umum untuk komponen dinding, strukturnya masih handal.

Kuda-kuda dan pondasi diberikan bobot yang besar. Dua kriteria ini sudah mewakili hampir 50\% kegiatan pengamatan (27 untuk kuda-kuda dan 24 untuk pondasi). Hal ini berhubungan dengan pentingnya dua hal tersebut dalam pendirian bangunan. Pondasi bangunan pre-pabrikasi ini terdiri dari tembokan menerus dengan ketinggian lebih dari $30 \mathrm{~cm}$ untuk menghindari kelembaban dengan tanah. Sementara itu kuda kuda papan paku adalah pilhan tepat karena titik berat rumah ini adalah pembuatan dinding, jendela dan pintu yang dapat dipasang dengan cepat (Surjokusumo et al. 2011). Kecepatan pemasangan inilah yang akhirnya juga merupakan salah satu kelebihan utama rumah pre-pabrikasi. Cepat terpasang dan cepat saat membongkar, mudah dipindahkan ke tempat lain sangat mendukung konservasi energi. Zimmermann (2012) menjelaskan bahwa rumah prepabrikasi mampu mendukung konservasi energi hingga $80 \%$, baik saat pembangunan maupun saat renovasi. 
Tabel 1. Hasil audit terhadap komponen bangunan rumah contoh tahan gemba pre-pabrikasi.

\begin{tabular}{|c|c|c|c|c|c|c|c|c|c|c|c|}
\hline \multirow[b]{2}{*}{ No } & \multirow{2}{*}{\multicolumn{2}{|c|}{ Objek pengamatan }} & \multirow[b]{2}{*}{$\begin{array}{l}\text { Bobot } \\
\text { (BB) \% }\end{array}$} & \multicolumn{5}{|c|}{ Hasil Pemeriksaan } & \multirow[b]{2}{*}{$\begin{array}{l}\text { Nilai } \\
\text { (Sn) }\end{array}$} & \multirow[b]{2}{*}{$\begin{array}{l}\text { BB } x \\
\text { Sn }\end{array}$} & \multirow[b]{2}{*}{ Ket } \\
\hline & & & & Baik & Sedang & $\begin{array}{l}\text { Rusak } \\
\text { ringan }\end{array}$ & $\begin{array}{l}\text { Rusak } \\
\text { sedan } \\
\mathrm{g}\end{array}$ & $\begin{array}{l}\text { Rusak } \\
\text { parah }\end{array}$ & & & \\
\hline 1. & $\begin{array}{c}\text { Pekerjaa } \\
- \\
- \\
- \\
- \\
-\end{array}$ & $\begin{array}{l}\text { n kuda-kuda } \\
\text { Kuda-kuda } \\
\text { Rangka atap } \\
\text { Pendukung } \\
\text { kuda-kuda } \\
\text { Penutup atap }\end{array}$ & $\begin{array}{l}27 \\
9 \\
8 \\
2 \\
8\end{array}$ & $\begin{array}{l}v \\
v \\
v \\
v\end{array}$ & & & & & $\begin{array}{l}5 \\
5 \\
5 \\
5\end{array}$ & $\begin{array}{l}45 \\
40 \\
10 \\
40\end{array}$ & \\
\hline 2. & Pondasi & & 24 & & $\sqrt{ }$ & & & & 5 & 96 & $\begin{array}{l}\text { - terlalu rendah } \\
\text { - pondasi beton } \\
\text { sebagian miring }\end{array}$ \\
\hline 3. & $\begin{array}{c}\text { Rangka d } \\
- \\
- \\
- \\
-\end{array}$ & $\begin{array}{l}\text { inding } \\
\text { Balok sloof } \\
\text { Kolom } \\
\text { Kolom praktis } \\
\text { Balok atas/ring } \\
\text { beton }\end{array}$ & $\begin{array}{l}19 \\
5 \\
5 \\
4 \\
5\end{array}$ & $\begin{array}{l}v \\
v \\
v\end{array}$ & $v$ & & & & $\begin{array}{l}5 \\
5 \\
5 \\
5\end{array}$ & $\begin{array}{l}20 \\
25 \\
20 \\
25\end{array}$ & $\begin{array}{l}\text { Kriteria ini untuk } \\
\text { bangunan } \\
\text { permanen, } \\
\text { disesuiakan } \\
\text { dengan } \\
\text { bangunan kayu. }\end{array}$ \\
\hline 4. & $\begin{array}{c}\text { Langit-lar } \\
- \\
- \\
\end{array}$ & $\begin{array}{l}\text { ngit } \\
\text { Rangka } \\
\text { Plafon } \\
\end{array}$ & $\begin{array}{l}10 \\
6 \\
4 \\
\end{array}$ & & & & & & $\begin{array}{l}0 \\
0 \\
\end{array}$ & $\begin{array}{l}0 \\
0\end{array}$ & tanpa plafon \\
\hline 5. & Dinding & & 8 & & $\sqrt{ }$ & & & & 4 & 32 & $\begin{array}{lr}\text { Ada } & \text { kotoran } \\
\text { burung } & \text { dan } \\
\text { serangga } & \\
\end{array}$ \\
\hline 6. & $\begin{array}{c}\text { Kusen/da } \\
- \\
- \\
\end{array}$ & $\begin{array}{l}\text { Pintu } \\
\text { Jendela }\end{array}$ & $\begin{array}{l}6 \\
3 \\
3 \\
\end{array}$ & $\begin{array}{l}v \\
v\end{array}$ & & & & & $\begin{array}{l}5 \\
5 \\
\end{array}$ & $\begin{array}{l}15 \\
15 \\
\end{array}$ & \\
\hline 7. & Lantai & & 4 & & $\sqrt{ }$ & & & & 4 & 16 & $\begin{array}{l}\text { Di beberapa } \\
\text { bagian lantainya } \\
\text { kayu } \\
\text { melengkung }\end{array}$ \\
\hline 8. & $\begin{array}{c}\text { Drainase } \\
- \\
- \\
- \\
- \\
\end{array}$ & $\begin{array}{l}\text { halaman } \\
\text { Alat } \\
\text { penerimaan air } \\
\text { buangan } \\
\text { Saluran } \\
\text { pembuangan } \\
\text { jalan } \\
\end{array}$ & $\begin{array}{l}1 \\
0,25 \\
0,5 \\
0,25\end{array}$ & & & & & & $\begin{array}{l}0 \\
0 \\
0\end{array}$ & $\begin{array}{l}0 \\
0 \\
0\end{array}$ & \\
\hline 9. & $\begin{array}{c}\text { Utilitas } \\
- \\
- \\
- \\
- \\
\end{array}$ & $\begin{array}{l}\text { Penerangan } \\
\text { Air } \\
\text { Pengatur udara } \\
\text { Telekomunikasi }\end{array}$ & $\begin{array}{l}1 \\
0,25 \\
0,25 \\
0,25 \\
0,25 \\
\end{array}$ & v & $\sqrt{ }$ & & & & $\begin{array}{l}5 \\
0 \\
0 \\
4\end{array}$ & $\begin{array}{l}1,25 \\
0 \\
0 \\
1,00 \\
\end{array}$ & \\
\hline \multicolumn{3}{|c|}{ TOTAL } & 100 & & & & & & & 401 & \\
\hline
\end{tabular}

Kategori keterandalan gedung

$$
\begin{array}{r}
=\frac{\text { Total BB } \times \text { Sn }}{500} \times 100 \% \\
=\frac{401,25}{500} \times 100 \%=80,3 \%
\end{array}
$$

Total nilai dikali dengan bobot, dibandingkan dengan total nilai akan didapatkan indeks keterandalan bangunan. Perhitungan hasil pada Tabel 2 menunjukkan bahwa Nilai keterandalan bangunan sebesar $80,3 \%$ Kondisi bangunan secara umum masih berfungsi, tapi tidak ada pemeliharan rutin. Hal ini disebabkan karena bangunan ini sudah tidak lagi digunakan untuk aktifitas harian. Hanya digunakan sesekali dan tidak tentu waktu penggunaannya. Namun kelebihannya adalah walaupun tidak digunakan rutin, namun kabel jaringan internet tetap tersedia. 
Tabel 2. Kategori nilai kondisi bangunan dan predikatnya

\begin{tabular}{|c|c|c|c|}
\hline No & $\begin{array}{l}\text { Nilai kondisi } \\
\text { bangunan (\%) }\end{array}$ & Predikat kategori & Keterangan \\
\hline 1. & $81-100$ & Baik & $\begin{array}{l}\text { bila kondisi pada komponen tersebut masih berfungsi } \\
\text { dengan baik dan ada pemeliharaan rutin }\end{array}$ \\
\hline 2. & $61-80$ & Sedang & $\begin{array}{l}\text { bila kondisi pada komponen tersebut masih berfungsi } \\
\text { meski tidak ada pemeliharaan rutin }\end{array}$ \\
\hline 3. & $41-60$ & Rusak ringan & $\begin{array}{l}\text { bila kerusakan terjadi pada komponen non struktural, } \\
\text { seperti finishing, penutup atap, pasangan plafon, } \\
\text { pasangan keramik, pasangan bata, plesteran }\end{array}$ \\
\hline 4. & $21-40$ & Rusak sedang & $\begin{array}{l}\text { bila kerusakan terjadi pada sebagian komponen non } \\
\text { struktural maupun struktural seperti struktur atap, } \\
\text { struktur langit-langit, struktur beton, lantai, dan lain- } \\
\text { lain. Pada fasilitas utilitas kerusakan yang terjadi } \\
\text { sudah mengganggu fungsional fasilitas tsb. }\end{array}$ \\
\hline 5. & $0-20$ & Rusak berat & $\begin{array}{l}\text { kerusakan terjadi pada sebagian besar komponen } \\
\text { bangunan, baik struktural maupun non struktural } \\
\text { yang bila setelah diperbaiki masih dapat berfungsi } \\
\text { dengan baik sebagaimana mestinya dengan } \\
\text { pembiayaan yang cukup mahal }\end{array}$ \\
\hline
\end{tabular}

Sumber: Departemen Permukiman dan Prasarana Wilayah (2002).

\section{Pengamatan Visual}

Pada saat pengamatan, ditemukan kerusakan pada pondasi beton maupun pondasi kayu. Pondasi beton terlihat mengalami damp akibat kelembaban yang sangat tinggi di dekat pondasi sehingga berpengaruh terhadap kayu yang ditopang olehnya. Terlihat kayu akhirnya juga

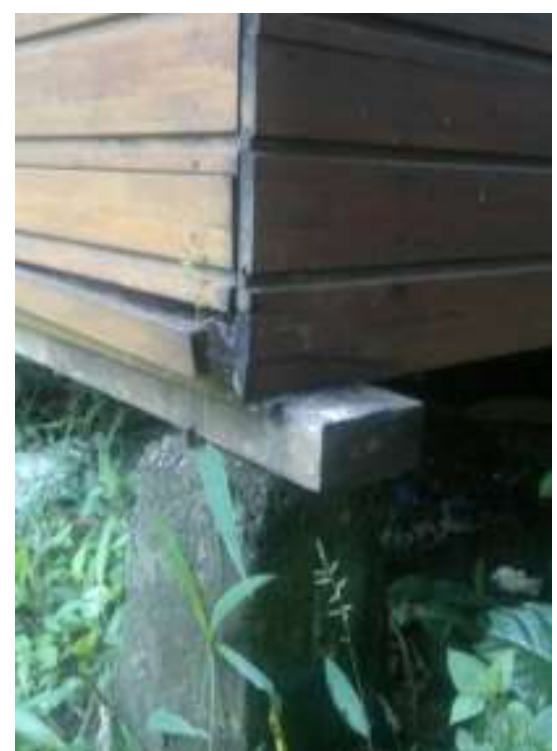

Gambar 8a. Damp pada bagian dinding luar mengalami pelapukan, baik kayu pondasi maupun dinding kayu. Tampilan dari bagian dalam pun demikian, tiang utama kayu penopang bangunan juga mengalami kerusakan. Jika tidak segera dilakukan treatment, maka kerusakan akan menjalar ke bagian bangunan lainnya (Gambar 8a, 8b, 9a, 9b).

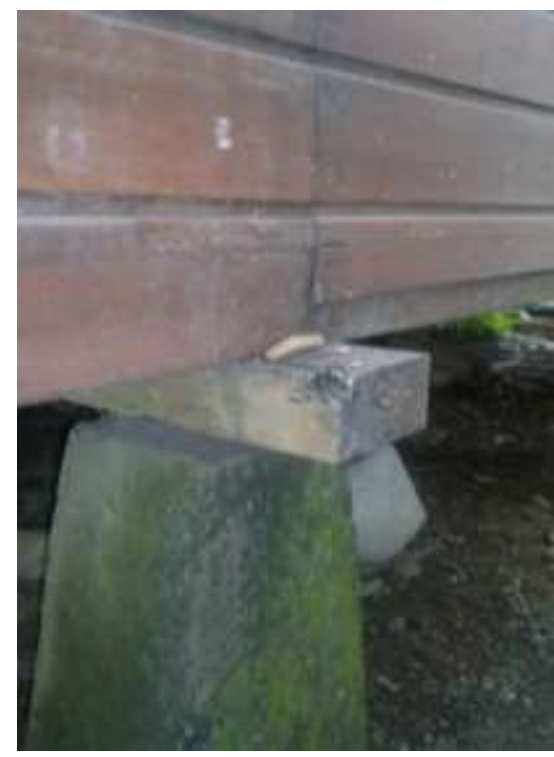

Gambar 8b. Damp pada pondasi kayu 


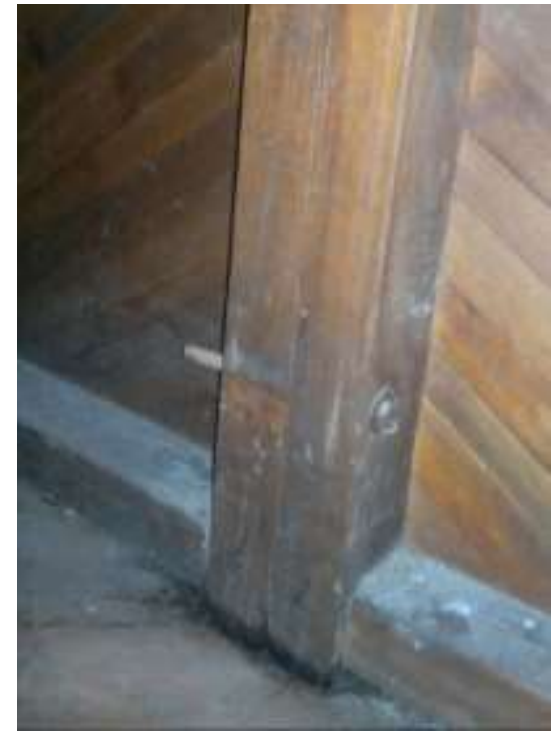

Gambar 9a. Damp pada pilar utama

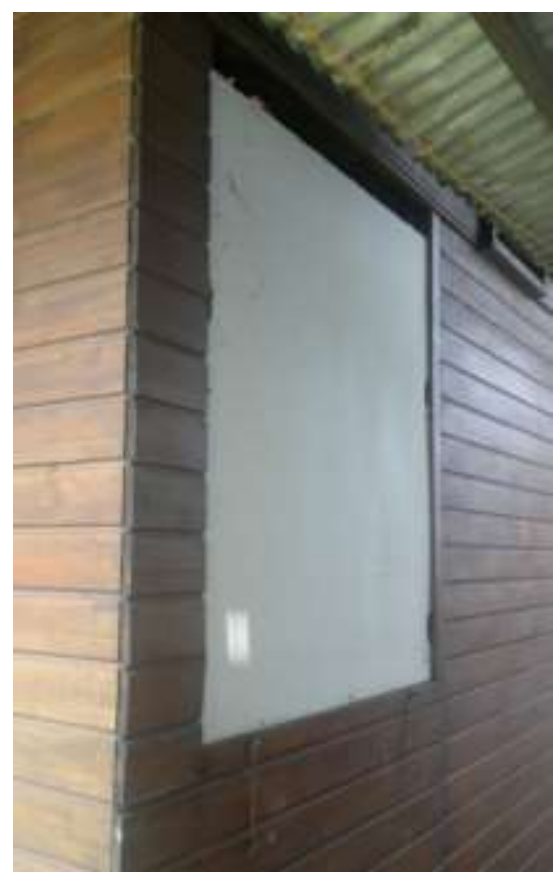

Gambar 10a. Jendela ditutup dengan kertas, menghambat proses sirkulasi udara

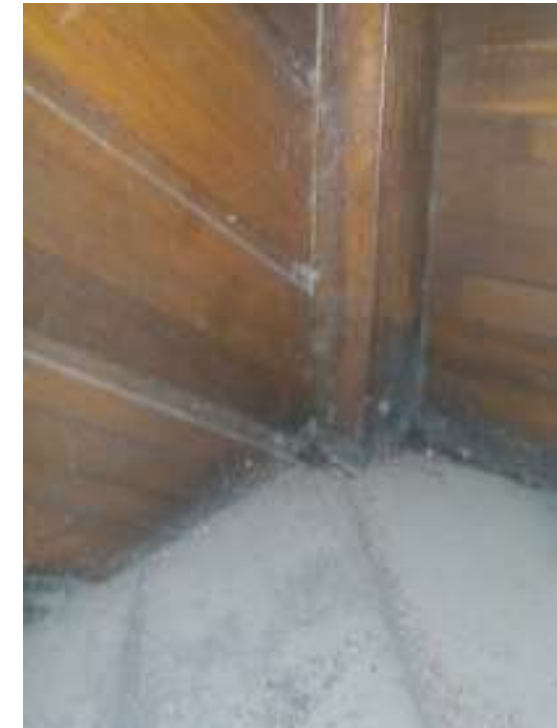

Gambar 9b. Damp pada sudut bangunan

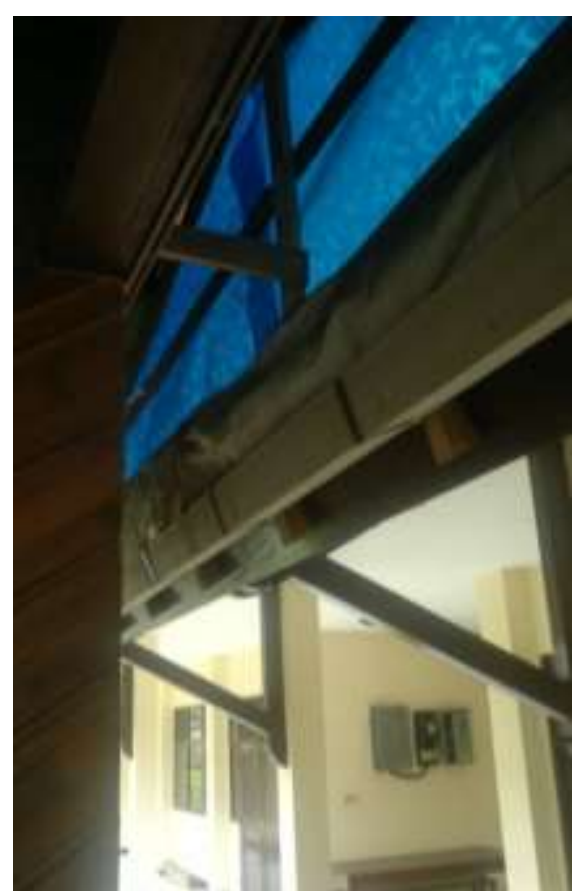

Gambar 10b. Pelindung dari hempasan air, kurang layak. 


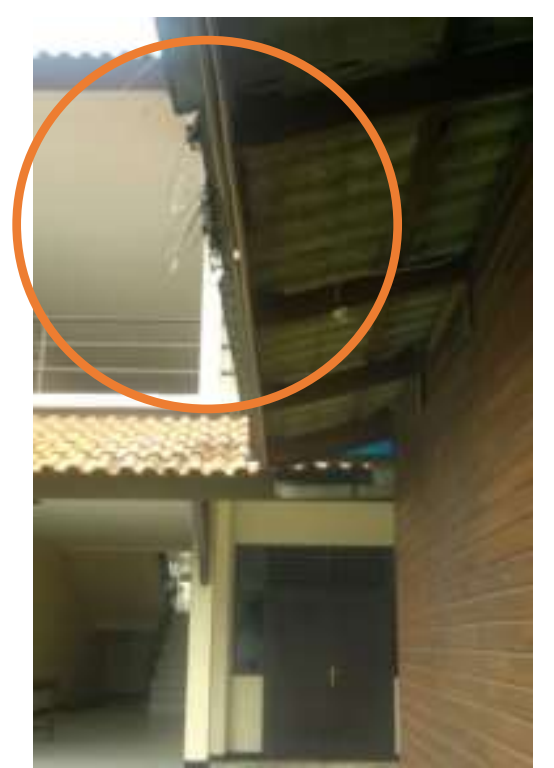

Gambar 11a. Sampah serasah daun pada atap bangunan

Selain damp, aspek lainnya yang mengurangi nilai bangunan dari kriteria sehat adalah sebagai berikut :

1. Pelindung dari hempasan air saat hujan kurang layak (Gambar 10b).

2. Jendela bagian belakang ditutup oleh kertas sehingga mengganggu estetika dan sirkulasi udara (Gambar 10a).

3. Adanya sampah daun diatap bagian belakang (Gambar 11a).

4. Debu yang sangat tebal memenuhi seluruh ruangan (Gambar 12).

5. Fungsi estetika kurang diperhatikan, misalnya penempatan paku sebagai pengganti pengait kunci jendela (Gambar 11b).

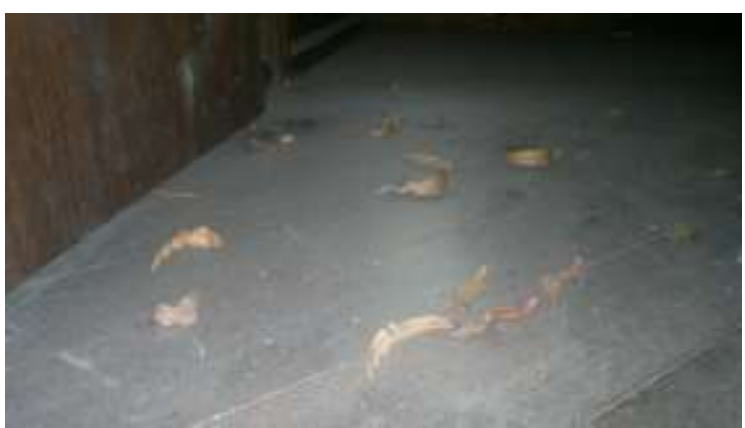

Gambar 12. Debu yang tebal dan sampah daun berserakan di dalam rumah.

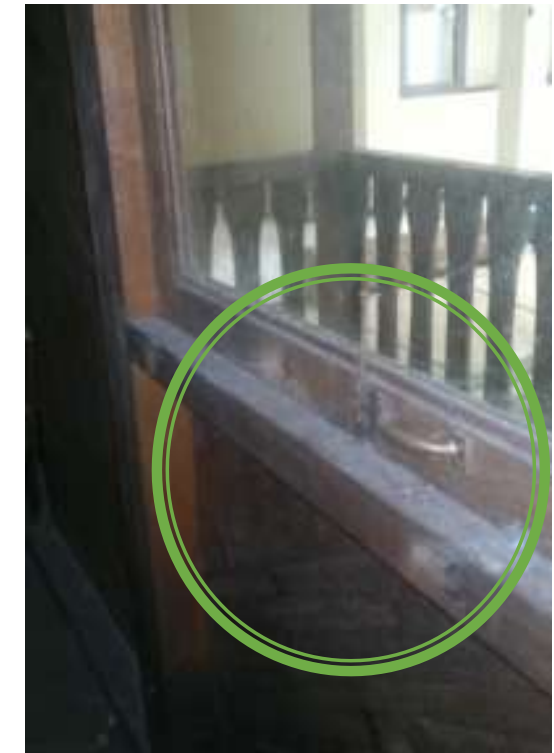

Gambar 11b. Debu tebal pada kusen jendela dan slot jendela digantikan dengan paku mengurangi keindahan

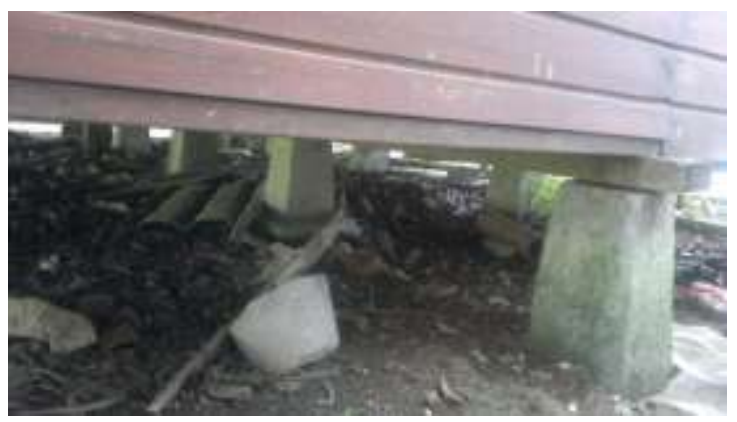

Gambar 13. Sampah di kolong bawah rumah.

Masalah lain yang terlihat yang jelas terlilhat dari luar bangunan adalah pondasi yang secara desain terlalu rendah. Akibatnya, sampah yang berserakan dibawah kolong pondasi sulit untuk dibersihkan (Gambar 13). Terlihat tumpukan sampah sisa sampel kayu, sisa bahan cor dan daun kering menghiasi bagian bawah pondasi. Jika hal ini berlangsung lama, maka selain mengganggu estetika, juga dapat memicu terjadinya damp, sehingga usia pelayanan pondasi kayu juga akan semakin pendek. Terbukti di beberapa titik, pondasi kayu sudah mengalami kerusakan (Gambar 8a). Untuk mengantisipasi hal ini harus dilakukan pembersihan secara rutin atau langkah kedua adalah mempertinggi pondasi beton yang membutuhkan dana lebih besar. 


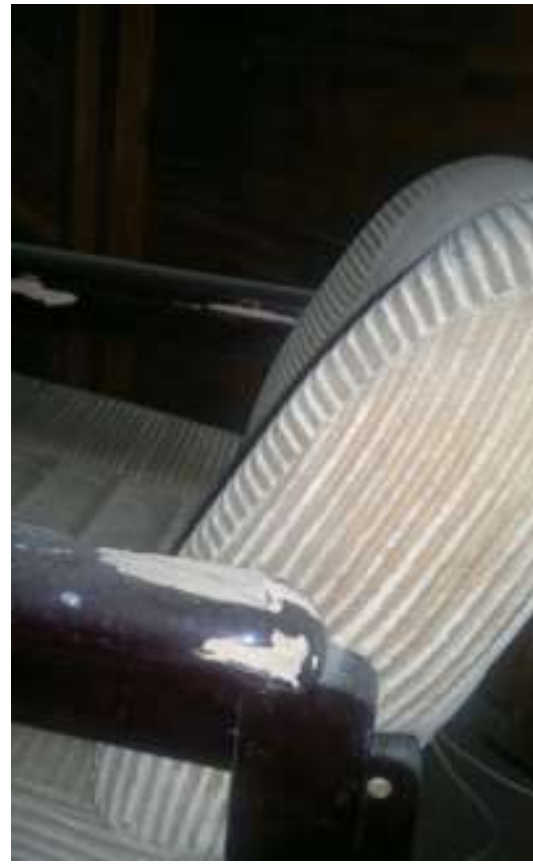

Gambar 14a. Serangan Kumbang Bubuk pada Kursi

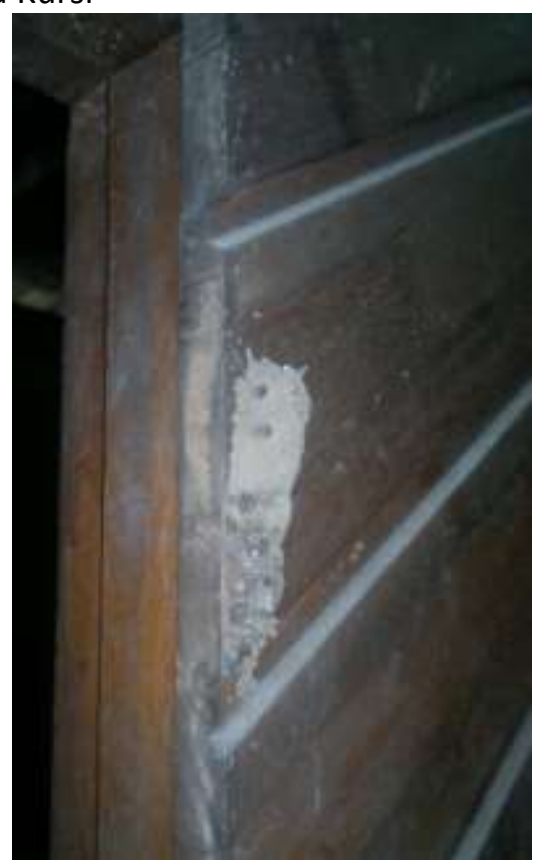

Gambar 14b. Sarang Kumbang pada dinding kayu

Organisme menyerang kayu dengan dua tujuan, yaitu sebagai makanan dan sebagai tempat tinggal. Kayu yang digunakan untuk membangun rumah contoh tahan gempa ini secara keseluruhan telah diberi anti rayap, sehingga praktis tidak terlihat adanya serangan rayap pada kayunya. Potensi serangan bisa ditimbulkan dari beberapa titik yang terlihat adanya damp, namun gejala serangan rayap belum terlihat.
Pada pintu masuk ke kamar, terlihat adanya sarang kumbang (Gambar 14b) namun belum terjadi kerusakan struktural. Perlu dilakukan pembersihan terhadap sarang kumbang tersebut agar tidak menjalar menjadi kerusakan yang lebih serius. Perabotan di dalam rumah terlihat berserakan, perabotan di ruang tamu tampak kotor dan tidak terawat, perabotan di kamar pun kurang lebih demikan. Ada dua buah kursi di dalam kamar, kayunya pegangan maupun kayu bagian bawahnya sudah terserang kumbang bubuk (Gambar 14a). Tidak jelas apakah serangan ini terjadi saat kursi tersebut diletakkan dirumah tersebut atau sebelum diletakkan sudah terjadi kerusakan.

Terdapat celah antara lantai kayu dengan tiang (Gambar 15). Celah ini berpotensi memudahkan organisme perusak kayu masuk dan menyerang perabotan lain yang tidak di aplikasi oleh antri rayap. Celah ini adalah kesalahan ketepatan ukuran saat pembuatan, seharusnya tidak ada celah satupun jika ukurannya tepat dan presisi.

Bagian terakhir yang diamati adalah utilitas atau sarana pendukung. Sarana pendukung ini memiliki kontribusi yang kecil pada penilaian pada komponen bangunan tetapi sangat terasa jika tidak ada karena berhubungan dengan kenyamanan penghuni. Diantara utilitas yang diamati adalah penerangan, sirkulasi udara, sarana telekomunkasi dan Air. Dari keempat hal tersebut, yang tersedia hanya penerangan dan sirkulasi, penerangan oleh lampu cukup baik, dan penerangan siang hari oleh matahari juga baik. Sirkulasi udara yang kurang baik, ditambahkan jendela belakang ditutup dengan kertas mengakibatkan suhu pada siang hari terasa panas. Sarana telekomunikasi yang tersedia adalah jaringan kabel internet dan masih berfungsi dengan baik (Gambar 16).

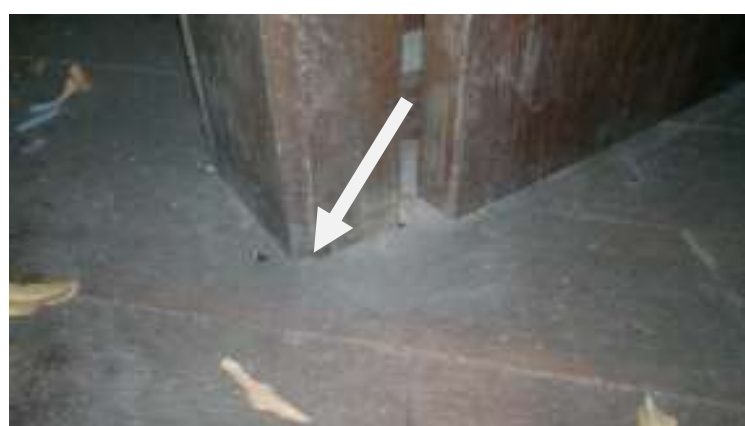

Gambar 15. Ada celah antara dinding lantai dan pilar kayu 


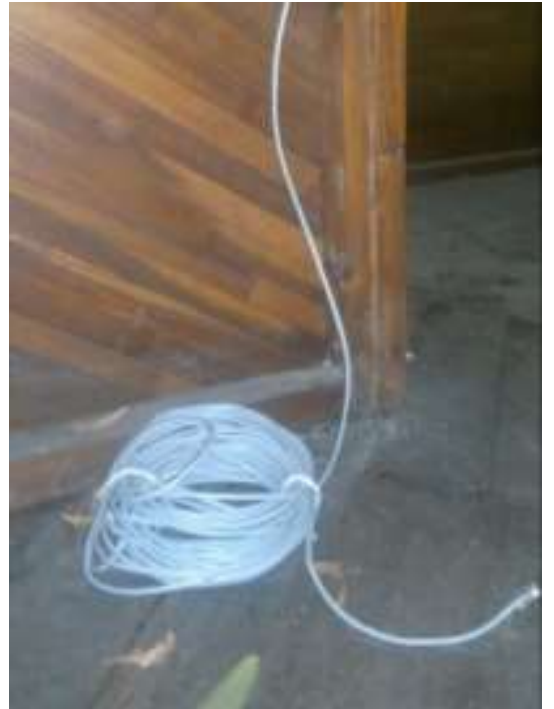

Gambar 16. Fasilitas jaringan internet kabel

\section{Kesimpulan dan Rekomendasi}

Dari berbagai kriteria dan penjelasan diatas, dapat disimpulkan beberapa hal sekaligus rekomendasi yaitu :

1. Rumah contoh tahan gempa prepabrikasi masih layak untuk dijadikan tempat hunian dengan sedikit rekayasa dan perbaikan.

2. Diperlukan pemeliharaan rutin, minimal membersihkan ruangan bagian dalam dari debu dan serasah daun tiap dua hari sekali. Termasuk didalamnya adalah pembersihan atap dari kotoran burung dan daun.

3. Memperbaiki sistem talang air di bagian kanan dan kiri yang berbatasan langsung dengan bangungan disamping kiri dan kanannya.

4. Membersihkan sampah yang terdapat pada bagian celah antara pondasi dan lantai.

5. Mempertinggi struktur pondasi untuk meminimalisir kontak dengan air.

6. Memperbaiki kesalahan desain prepabrikasi dengan menutup celah dan lubang yang terbentuk di beberapa titik saat pemasangan.

7. Melengkapi bangunan dengan sarana pendukung lainnya sehingga lebih layak huni.

\section{Pustaka}

Cahyono TD. 2001. Pengujian Efikasi Bifenthrin Sebagai Bahan Pengawet Kayu Lapis Terhadap Serangan Rayap Tanah Coptotermes curvignathus Holmgren di Lapangan IPB (Bogor Agricultural University).

Cahyono TD. 2016. Identifikasi Tingkat Serangan dan Jenis Rayap yang Merusak Bangunan di Kota Ambon. Bimafika: Jurnal MIPA, Kependidikan dan Terapan. 3(2).

Karlinasari L, Nugroho N, Surjokusumo S. 2006. Pembangunan rumah contoh tahan gempa untuk daerah bencana dengan sistem pre-pabrikasi.

Lestari SDW. 2013. Keragaman Jenis Rayap dan Intensitas Kerusakan Bangunan di Perumahan Taman Darmaga Permai I, Ciampea, Bogor.

Roychansyah MS. 2006. Perkembangan Rumah Prefabrikasi. Repository Civitas Gadjah Mada University.

Surjokusumo H, Rachman O, Nugroho N. 2011. Optimation of mangium wood utilization as component of the prefabricated seismic resistance house.

Watt DS. 2009. Building pathology: Principles and practice: John Wiley \& Sons.

Zimmermann M. 2012. Prefabricated systems for low energy renovation of residential buildings. AECOM Ltd.: Birmingham, $U K$.

小松幸平. 2012. アカシアマンギュウム材を 用いたプレファブ型モデル耐震木造 住宅建設のインドネシアでの試み. 